This item was submitted to Loughborough's Research Repository by the author.

Items in Figshare are protected by copyright, with all rights reserved, unless otherwise indicated.

\title{
Affective commitment within the public sector: Antecedents and performance outcomes between ownership types
}

PLEASE CITE THE PUBLISHED VERSION

https://doi.org/10.1080/14719037.2018.1444193

\section{PUBLISHER}

(C) Taylor \& Francis

\section{VERSION}

AM (Accepted Manuscript)

\section{PUBLISHER STATEMENT}

This is an Accepted Manuscript of an article published by Taylor \& Francis in Public Management Review on 1 March 2018, available online: http://www.tandfonline.com/10.1080/14719037.2018.1444193.

\section{LICENCE}

CC BY-NC-ND 4.0

\section{REPOSITORY RECORD}

Hodgkinson, lan, Paul Hughes, Zoe J. Radnor, and Russell J. Glennon. 2019. "Affective Commitment Within the Public Sector: Antecedents and Performance Outcomes Between Ownership Types”. figshare. https://hdl.handle.net/2134/32013. 


\title{
Affective Commitment within the Public Sector: Antecedents and Performance Outcomes between Ownership Types
}

IAN R. HODGKINSON (corresponding author) ${ }^{\mathbf{1}}$

The School of Business and Economics, Loughborough University, Loughborough, UK.

PAUL HUGHES ${ }^{2}$

Leicester Castle Business School, De Montfort University, Leicester, UK.

ZOE RADNOR ${ }^{3}$

School of Management, University of Leicester, Leicester, UK.

RUSS GLENNON ${ }^{4}$

Nottingham Business School, Nottingham Trent University, Nottingham, UK.

${ }^{1}$ Loughborough University, School of Business and Economics, Loughborough, Leicestershire. LE11 3TU. UK. Tel: +44 (0)1509223865. Email: I.R.Hodgkinson@lboro.ac.uk.

${ }^{2}$ Leicester Castle Business School, Hugh Aston Building, De Montfort University, The Gateway, Leicester. LE1 9BH. UK. Tel: +44 (0) 1162577031. Email: paul.hughes@dmu.ac.uk.

${ }^{3}$ School of Business, University of Leicester, Leicester. LE1 7RH. UK. Tel: +44 (0) 01162297590.

Email: zjr1@leicester.ac.uk.

${ }^{4}$ Nottingham Business School, Nottingham Trent University, 50 Shakespeare Street, Nottingham. NG1 4FQ. UK. Tel: +44 (0) 1158484 508. Email: russ.glennon@ntu.ac.uk.

\begin{abstract}
How to generate affective commitment and realize its performance potential is deemed critical to public management. But in the context of service outsourcing, does ownership type influence its antecedents and performance outcomes? Drawing on postal survey data for English leisure providers, we find training is an antecedent across public and private ownership types; performance appraisal is an antecedent for private ownership only; while performance-related pay carries an insignificant effect. Affective commitment holds business and customer performance outcomes for public ownership, but insignificant effects are observed for external ownership types. Implications of this contextual variation for public management theory are discussed.
\end{abstract}

KEYWORDS affective commitment; antecedents; outcomes; ownership type; training; performance appraisal; performance-related pay; performance; performance management. 


\section{Introduction}

Organizational employees are often viewed as the major factor differentiating successful and unsuccessful organizations and one strategy to exploit this is to build employees' organizational commitment (Mostafa, Gould-Williams, and Bottomley 2015; Whitener 2001). Commitment is categorized into three components: continuance, normative and affective. Employee's awareness of the costs related to exiting an organization (continuance) or their feeling of obligation to continue employment (normative) are considered to be beyond organizational control. Only affective commitment can be 'managed', according to Su, Baird, and Blair (2013). This refers to the employee's emotional attachment to, identification with, and involvement in the organization (Meyer, Stanley, Herscovitch, and Topolnytsky 2002) and is most closely associated with public service performance (Hansen and Kjeldsen 2017; Kim 2005; Mostafa et al. 2015). As Hansen and Kjeldsen (2017) emphasize, explaining affective commitment is of key importance to public management, both to ensure commitment development and also to harvest its performance potential. Yet the antecedents and performance outcomes of affective commitment must be understood within the context of service outsourcing if it is to be accurately explained.

External ownership types such as private agents or non-profit trusts are typically assumed to deliver better results, relative to in-house public delivery (Andrews, Boyne, and Walker 2011). This belief has underpinned New Public Management (NPM) rhetoric and the transference of performance management tools from the private to the public sector (Williams, Rayner, and Allinson 2012). Yet as Andrews et al. (2011, 301-02) note, 'such claims often amount to little more than ideological assertions based on the preferences of protagonists. Empirical evidence is therefore required to better understand the effects of ownership'. Thus, examining performance management tools as antecedents of affective commitment and the performance potential of affective commitment between ownership types is central to public administration and management investigation. Further, this serves to highlight how (different) public service organizations invest in employees to generate commitment and whether service performance ensues, consistent with the service-dominant approach (Osborne, Radnor, Kinder, and Vidal 2015). While shared service delivery between public, non-profit, and private ownership types is common place, the question remains: Does ownership type influence the antecedents and outcomes of affective commitment?

This question is explored in the English leisure service setting where outsourcing to external providers has been prevalent. A two-stage empirical model is adopted ${ }^{1}$. First, we assess the relationships between performance management tools and affective commitment by ownership type (model 1). Second, since the performance legacies of affective commitment are often overlooked, we examine its implications across business, customer, and social performance dimensions for each ownership type (model 2). Additional analysis then compares the three ownership types to determine whether significant differences in the prevalence of antecedents

\footnotetext{
${ }^{1}$ For clarification as raised by the review team, this is not a mediation model. We are focused on affective commitment between ownership types. A mediator is an explanatory for how an Independent Variable can affect a Dependent Variable. As such the antecedent—commitment—outcome relationship is a completely different causal model that demands its own theoretical lens.
} 
and commitment exist. Collectively, the contribution of this study is three-fold. First, we contribute to public management theory by addressing a need for a clearer understanding of employees' affective commitment, including its antecedents and performance outcomes, as called for by Hansen and Kjeldsen (2017), Kim (2005), and Mostafa et al. (2015), respectively. Second, we account for an overlooked situational factor-ownership - that might influence the validity of reported commitment antecedent and outcome effects at the disaggregated level (see O'Toole and Meier 2015). In doing so, we provide evidence to the effects of ownership in the sector, as called for by Andrews et al. (2011). Finally, drawing on motivation crowding theory, we demonstrate the role of intrinsic and extrinsic performance management tools for different ownership types. This extends the debate about performance management from information use to incentivizing tools, as called for by Jacobsen and Andersen (2014).

The article is structured as follows: first, an integrated literature review and hypotheses section frames the investigation of affective commitment and positions the study hypotheses alongside motivation crowding theory. Next, the two-stage empirical model is tested between ownership types, findings are reported, and the additional analysis is presented. Then, contextual variation in the findings and implications are discussed, in light of the study's limitations.

\section{Literature review and hypotheses}

A central theme of commitment research in the public management literature has been the examination of sectoral differences, where employee commitment levels between the public, non-profit, and private sectors have been shown to vary. For instance, Goulet and Frank (2002) report that employee commitment is higher in for-profit firms, followed by non-profit, and then public organizations where employees are reported to have the lowest level of commitment. Additional studies have gone on to demonstrate mixed-findings for the relationship between 'sector' and commitment. Boyne (2002) observes that public sector employees have weaker organizational commitment than their private sector counterparts; Lyons, Duxbury, and Higgins (2006) support and extend this finding by demonstrating that private sector employees display greater organizational commitment than employees in public and parapublic sectors; on the other hand, Bullock, Stritch and Rainey (2015) demonstrate that across countries public sector employees expressed higher levels of organizational commitment than found in the private sector; while Hansen and Kjeldsen (2017) report that there appear to be no significant sector differences in employees affective organizational commitment.

Appendix A documents recent investigation of affective commitment antecedents and outcomes in the public management literature. In every case service providers have been treated in a homogenized way and/or with the focus on differences found (or not) between the public and private sectors. The studies cited have been invaluable in shedding further light on affective commitment antecedents or outcomes, but there remains a long standing need to move beyond simple public versus private comparisons (Goulet and Frank 2002). Despite this call, the variation of ownership within the public sector and its influence on affective commitment antecedents and outcomes remains neglected. This neglect of the service outsourcing context is a 
clear deficiency of the public management literature. Specifically, how affective commitment is developed between public, non-profit and private ownership types (antecedents) and the potential service performance gains of commitment (outcomes) for these different providers remains at a surface level of understanding. This is largely because ownership has been overlooked, but this situational factor is essential to developing the public management and performance research agenda (e.g. O'Toole and Meier 2015). For instance, affective commitment is generated by employees' work experiences post entry (Meyer et al. 2002), therefore, it is what public service organizations do that matters most for affective commitment generation. This would suggest, then, that variation will exist between different ownership types. Moreover, ownership type will likely influence the performance goals that employees are committed to and, thus, the achievement of such goals (Williams et al. 2012). Subsequently, we should not treat public service organizations as a homogeneous set since variation in antecedent and outcome effects within the public sector are likely. Investigating this variation is necessary for a more accurate picture of affective commitment in public management to emerge.

\section{Antecedents: intrinsic and extrinsic}

As Butterfield, Edwards, and Woodall (2004, 397) comment, 'performance management is a key element in the repertoire of NPM techniques drawn from Human Resource Management...these include...identifying staff training and development needs; assessing the results through personal appraisal using relevant performance indicators, performance agreements or contracts'. The use of hard performance management tools particularly, such as 'monitoring and evaluating individual contributions and providing both incentives and disincentives for employees to achieve relevant objectives' is connected to NPM (Campbell, Lee, and Im 2016, 798). Training, performance appraisal and PRP are, thus, expected in the NPM-oriented settings described by Hansen and Ferlie (2016) since they reflect the broader NPM themes of employee empowerment, performance evaluation, and a shift from processes to outcomes (Su et al. 2013).

Training and/or reward management have featured heavily in recent investigations of antecedents of commitment (e.g. Castaing 2010; Miao, Newman, Sun, and Xu 2013; Kooij et al. 2010; Mostafa et al. 2015; Park and Rainey 2007; Su et al. 2013). Drawing on motivation crowding theory there is a distinction to be made here. Training is theorized to be intrinsically motivating for employees as it is related to advancement, growth, and accomplishment supporting workers to achieve higher levels of functioning (Kooij, Jansen, Dikkers, and De Lange 2010). Performance appraisal and PRP, on the other hand, are both theorized as extrinsically motivating, given their association with outcomes and monetary rewards, i.e. they are control-oriented (Jacobsen and Andersen 2014). The former shapes a long-term social rather than a short-term economic exchange with employees, like the latter (Mostafa et al. 2015). Though fundamentally different (i.e. supportive and 'soft' versus controlling and 'hard'), their individual effects between ownership types have not been examined.

In the wider HRM literature, training is a means to develop working conditions that enhance employees' ability to identify with organizational objectives and values, rather than 
seeking to control individual behaviors (Giauque et al. 2013). Thus, training is defined as a planned process to 'modify attitudes, knowledge or skill behaviour through learning experience' (Reid and Barrington 1994, 7). Following motivation crowding theory, such a performance management intervention is seen as supportive, enabling employees' to do their role better and/or help others more effectively, which in turn increases commitment (Jacobsen and Andersen 2014). This is referred to as the crowding-in effect, which is generated through a long-term social exchange of support (Jacobsen and Andersen 2014; Miao et al. 2013). In other words, in signalling to the employee that they are valued a reciprocal exchange of commitment occurs between the employee and their organization (Miao et al. 2013). This social exchange has driven research on high performance human resource practices, which 'is premised on the assumption that organizations want to promote workforce commitment by investing in employees (the resource-based or “soft” approach to HRM)' (Mostafa et al. 2015, 748). Though training has received limited attention in the public management literature (Kroll and Moynihan 2015), Bartlett (2001), Gould-Williams (2004), and Mostafa et al. (2015) document a positive relationship between training and affective commitment (when service organizations are treated as a homogenous set). Therefore:

Hypothesis 1: Training is positively related to affective commitment for (a) public, (b) non-profit, and (c) private ownership types.

As described by Jacobsen and Andersen (2014, 1012), extrinsic performance management tools incentivize employees 'through the use of formalized contracts that specify a required level of performance in a given period, involve monitoring of performance, and state consequences in the form of either rewards for superlevel performance or sanctions for sublevel performance'. First, performance appraisal as a mechanism for monitoring performance is increasingly relevant to contemporary public management (Christensen, Whiting, Im, Rho, Stritch, and Park 2013). Performance appraisal focuses on individuals’ performance potential, which encourages 'employees to identify with the goals of the organization and work hard to accomplish those goals' (Whitener 2001, 517). The subsequent path-goal motivations create an extrinsically motivated psychological bond between employee and organization. Subsequently, when administered effectively and objectively, performance appraisal has been observed to increase affective organizational commitment (Brown, Hyatt, and Benson 2010). This is particularly pertinent to agencies in competitive public service settings that are urged to link performance data to employee-centred performance development to mobilize affective commitment (Poister 2010). Second, PRP schemes reward output and focus on working objectives, i.e. extrinsic monetary rewards outside of their work (Jacobsen and Andersen 2014). In the management literature, internally equitable and externally competitive compensation systems have been shown to positively affect employee commitment (Whitener 2001). In recent years there has been a resurgence of interest in PRP in the public management literature (Bellé 2015; Perry, Engbers, and Jun 2009). Where PRP is intended to boost the efficiency of the public 
sector (Weibel, Rost, and Osterloh 2009), increasing the net benefits for employees of doing their work to an expected level (Jacobsen and Andersen 2014).

Motivation crowding theory points to the summation that the extrinsic performance management tools of appraisals and PRP are less suited to public ownership than external ownership types, however. Specifically, the crowding-out effect that occurs when a performancecontingent monetary incentive creates the employee perception that action is externally driven rather than internally appealing (Frey and Jegen 2001) reduces public service motivation (Jacobsen, Hvitved, and Andersen 2014; Weibel et al. 2009); and logic would suggest commitment also. For instance, Markovits, Davis, Fay, and Dick (2010) highlight that civil servants' organizational commitment is related to intrinsic rather than extrinsic incentivization. In other words, an individual would choose to work in the public sector rather than the private sector even if the economic rewards were not comparable because of the intrinsic and altruistic value of working for a public service (Lyons et al. 2006). At the disaggregated level, this is expected to be the case for public ownership specifically, as this setting is less 'business-like' relative to external ownership types (Carlos Pinho, Rodrigues, and Dibb 2014). Here, employees are less likely to be motivated by individual-level performance assessment and reward given their altruistic motives that serve to increase commitment (Stazyk, Pandey, and Wright 2011). Thus, increasing use of performance appraisals and PRP magnifies the crowding-out effect for public ownership. In contrast, external ownership is likely to benefit from their employees' understanding of how performance is linked to rewards given expected extrinsically driven pathgoal motivations. Indeed, in these settings extrinsic incentivizing tools are reported to have a positive relationship with commitment (Bennett, Iossa, and Legrenzi 2003; Su et al. 2013). Thus:

Hypothesis 2: Performance appraisal is more positively related to affective commitment for external (a) non-profit and (b) private ownership types, relative to (c) public ownership.

Hypothesis 3: PRP is positively related to affective commitment for (a) non-profit, and (b) private ownership types, but (c) negatively related to affective commitment for public ownership.

\section{Performance outcomes}

It is generally accepted that affective commitment is positively associated with organizational performance (Kim 2005) and, thus, carries implications that extend beyond the individual (Mostafa et al. 2015). When examining performance it is essential to recognize that 'virtually all public organizations are tasked with multiple goals' (O’Toole and Meier 2015, 239). Since focusing on one performance criterion is problematic as a biased picture may emerge (Andersen, Boesen, and Pedersen 2016), three performance dimensions are considered. First, the customer dimension is consistent with UK policy reform that has emphasized customer satisfaction and preferences (Hodgkinson and Hughes 2014); second, the business dimension captures the need for market-driven income for economic survival and service sustainability (Hansen and Ferlie 2016); third, the social dimension represents an emphasized outcome of UK sport policy. 
However, whether affective commitment will have a consistent positive relationship across these different dimensions for each ownership type is not clear.

As Williams et al. (2012, 2617) highlight, 'regardless of organisational demands, it is ultimately a person's inner drive, combining his or her beliefs, values, character and reflexive consciousness, that determines behaviour'. For this reason, individual's personal commitment to objective performance goals may vary (Williams et al. 2012). Congruence or alignment between the individual and organizational goals may, therefore, be largely dependent on the type of ownership being examined. To elaborate, external ownership types are more favourably disposed towards NPM and its business-centred outcomes, relative to in-house public ownership (Carlos Pinho et al. 2014). External ownership types receive limited public subsidy and need to ensure a healthy revenue stream for economic survival, or to reinvest surplus back into the service (Audit Commission 2006). They are subsequently more likely focused on meeting customer needs for economic survival (Andersen and Jakobsen 2011). For example, the Audit Commission (2006) report that private ownership is principally concerned with attracting higher income groups; similarly, the hard resource constraints imposed on non-profit ownership also drives revenue generation (alongside their social mission attributed to charitable status).

In contrast, it is anticipated that public ownership employees will be more committed to the altruistic values of the 'welfare state' and access for all as opposed to business objectives. This may in part be because such providers enjoy the benefit of soft resource constraints that external ownership does not benefit from (though this has been receded in recent times of austerity). Also intrinsically motivated employees are less likely to take actions that increase measured performance (such as profitability) in favor of actions that only increase value (e.g. customer performance and social performance) (Heinrich and Marschke 2010). Indeed employees under public ownership may be uncomfortable with the values associated with business objectives and, thus, are unlikely to be committed to the achievement of such goals, which would weaken business performance specifically (e.g. Williams et al. 2012). Hence:

Hypothesis 4: Affective commitment is positively related to business performance for external (a) non-profit and (b) private ownership types, but (c) negatively related for public ownership.

Hypothesis 5: Affective commitment is positively related to customer performance for (a) public, (b) non-profit, and (c) private ownership types.

Hypothesis 6: Affective commitment is positively related to social performance for (a) public and (b) non-profit ownership types, but (c) negatively related for private ownership.

The hypothesized relationships are shown in Figure 1: first, we examine the performance management tools $\rightarrow$ affective commitment paths between ownership types (model 1); second, we examine the affective commitment $\rightarrow$ performance paths between ownership types (model 2). 


\section{Methods}

\section{UK Policy context}

The Best Value regime introduced by New Labour in 1997 demonstrated a mainstreaming of the previous Conservative orthodoxy around contestability and competition. This was framed as a reform to improve services rather than simply control expenditure (Martin and Hartley 2000). New Labour's Best Value explicitly encouraged partnerships between the private and voluntary sectors and local government (Entwistle and Martin 2005). This returned power to local government to choose who manages services and a more generalized involvement of the private and voluntary sectors in delivering public services. Mixed service economies, where public organizations may be part of a network or partnership or may contract out parts of their services to other providers (Boyne 2003), thus, emerged from policy intervention. The year 2007 is the focus of this study and represents the culmination of New Labour's Best Value regime and nearly two decades of regulatory effort to encourage contracting-out among English local governments (Alonso, Andrews, and Hodgkinson 2016).

\section{Data collection}

We examine leisure facilities in England and identify public, non-profit, and private ownership types that coexist in service delivery to ensure comparability in antecedents, affective commitment, and outcomes. Primary data collection involved a postal survey to 1060 local government-owned facilities in England, where at least one of the following is available to members of the general public on a pay and play or membership basis: health and fitness suite, swimming pool, or sports hall. The facility manager was targeted as the key informant consistent with previous investigation of the strategic actions of these service providers (e.g. Hodgkinson and Hughes 2014). Survey administration followed a four-stage protocol comprising (1) prenotification letter, (2) first questionnaire package, (3) first reminder letter, and (4) replacement questionnaire pack. To protect against common method variance biasing our data, we followed the prescriptions of Spector and Brannick (1995) in developing the questionnaire and ensured that measurement scales were placed in random order; non-idealized responses and wording neutrality were adopted; questionnaire length was short (three pages); and detailed instructions for completion. A total of 280 responses were received: 152 public (from 540; response rate: 28\%), 75 non-profit (from 287; response rate: 26\%), and 53 private (from 233; response rate: $23 \%)$. Objective secondary data complements the primary data collection by providing detail on ownership type and social performance from two separate audits; conducted by an independent commercial firm that specializes in leisure intelligence.

\section{Measures}

Ownership type

In England there are predominantly three ownership types responsible for the delivery of public sector leisure facilities: public provision by local government; non-profit provision by a third sector trust; and, private provision by a private sector management contractor. Local government 
are the ultimate custodians of these facilities, but the ownership (i.e., management and operation) can be leased on a medium to long-term basis to external ownership types (e.g. non-profit and private). This is an objective measure of ownership type.

\section{Training, performance appraisal, $P R P$, and affective commitment}

First, to capture the importance placed on training two items are adapted from Snell and Dean's (1992) battery of eight items that capture the comprehensiveness of training. Six of the original items were deemed inappropriate for this study as they concern the structure (e.g. 'How formal or structured is the training process?') or frequency (e.g. 'On average, how many hours of formal training does a typical member of your work unit receive per year?') of training, rather than the importance of training to the organization. While the value attached to training is important to discern, for the purposes of this study the perceived effectiveness is also of relevance. Delaney and Huselid (1996) draw on two items to capture training effectiveness and we adapt one of these items that is explicitly focused on effectiveness and chose to drop the other that was more concerned with frequency of training ('Within the last 2 years, how many employees participated in formal job training?'); resulting in a three-item scale.

Second, to capture performance appraisal, three items are adapted from Snell and Dean's (1992) original nine-item scale. Performance appraisal is a tool to measure employee performance and to emphasize the importance of performance among employees, which the two items selected capture. Other items from the original scale focus on the link between appraisal and performance pay (e.g. 'How closely are raises, promotions, etc., tied to performance appraisal?') and hence were not included given that PRP is examined as a separate construct. The process involved in performance appraisal was also not the focus of this study; hence items that captured this element of appraisal were not included (e.g. How many people provide input to the performance evaluation of each employee?'). On the basis of the exploratory factor analysis, of the three selected one item was dropped for purposes of analysis as it did not meet the expected loading threshold: 'Do discussions focus on present performance or future performance?'.

Third, for PRP two items are adapted from the original three-item scale developed by Deckop et al. (1999) to measure the link between performance and pay. Since this scale was developed with the private sector in mind, one item of the original scale was not included as this focused on the relationship between increased 'productivity' and higher pay for employees, which we felt was not transferable to this public service context.

Finally, three items are adapted from Becker et al.'s (1996) five-item scale to gauge affective commitment. In order to reduce questionnaire length, we chose not to include the additional two items: "When I talk about this organization, I usually say "we" rather than "they"' and 'When someone praises this organization, it feels like a personal compliment'.

\section{Performance}

Service performance is considered from a multi-dimensional perspective. First, customer performance items comprise customer satisfaction, customer value, quality of services, and 
development of services. Second, business performance items comprise new customer sales, profitability, market share, and marketing (the ability to refine organization activities now and into the future to sustain superior performance) are adopted, consistent with Hodgkinson and Hughes (2014). Third, secondary objective social performance data is calculated on the basis of the postcode distribution of facility usage compared with the postcode analysis of the population in the facility's catchment area. A percentage of target groups accessing provision within the given facility catchment area is then determined. Relevant target groups are those that are recreationally disadvantaged as identified in UK sport policy and are defined as welfare borderline, municipal dependency, and twilight subsistence (see Appendix B).

\section{Controls}

The cost (£) of facility access at a single point in time (i.e. pay to play at the facility) and over multiple time points (i.e. facility membership) are controlled for in both model 1 and model 2. The move to increased service externalization and away from traditional in-house public delivery is expected to result in certain service priorities such as social welfare being degraded in search of revenue. This is captured by the control variables that draw on objective pricing data, which could be expected to both influence employee affective commitment (e.g. higher pricing may conflict with the altruistic values of public ownership) and service performance (e.g. business performance would likely benefit from higher pricing).

Each measure item was assessed using attitude statements where responses were measured on a seven-point Likert-type scale and all items were subjected to confirmatory factor analysis (CFA) in LISREL 8.8 with maximum likelihood estimation. The model fit statistics demonstrate strong model fit: $\chi^{2}=190.29$; degrees of freedom $=120 ; p=0.00$; Root Mean Square Error of Approximation $=0.05$; Conditional Fit Index $=0.98$; Normed Fit Index = 0.95; Incremental Fit Index $=0.98$; Goodness of Fit Index $=0.93$; Standardized Root Mean Square Residual $=0.04$. Appendix $\mathrm{C}$ provides details of the wording of all measure items, their reliability statistics and the factor loading for each item. All constructs exhibit acceptable reliability. 'Affective Commitment' is an exception as the AVE value is below 0.5. This is not a concern, however, as the square root of this value exceeds every correlation and so demonstrates discriminant validity. Results of correlation and descriptive analyses are presented in Table 1. We compare the CFA results with a one-factor CFA model to assess for common method variance problems and find the one-factor model to be significantly poorer in comparison $\left(\chi^{2}=\right.$ 938.97; $\mathrm{df}=135$; RMSEA = 0.15; CFI = 0.79; NFI = 0.77; IFI = 0.79; GFI = 0.72; Standardized RMR $=0.11$ ). Taken together, the results imply the constructs contained in the model are distinct and common method variance is not present.

\section{...Insert Table 1 About Here...}

\section{Data analysis}

Multiple linear regression analysis is used to test the hypothesized relationships between antecedents and affective commitment for each ownership type, and between affective 
commitment and the three performance dimensions for each ownership type. Data and the results are presented in Table 2 (antecedents) and Table 3 (outcomes). To more clearly understand the levels of adoption of performance management tools between ownership types and their respective levels of affective commitment, we employ multivariate analysis of variance (MANOVA) with post hoc analysis using the Scheffé Test. This is a post hoc test for comparing groups and identifying which comparisons among groups have statistically significant differences. Findings are presented in Table 4.

\section{Results}

\section{Antecedents}

Hypothesis 1 proposed that training is positively related to affective commitment for (a) public, (b) non-profit, and (c) private ownership types. Training does have a significant positive direct effect for public $(\beta=-0.01 ; p \leq 0.01)$ and private $(\beta=0.30 ; p \leq 0.05)$ ownership types, providing partial support for hypothesis 1 . While the relationship holds for non-profit ( $\beta=0.27 ; \mathrm{p} \leqslant 0.1$ ) ownership, we caution the result due to the non-significant regression model ( $F$-value $=0.89$; ns).

Hypothesis 2 posited that performance appraisal is more positively related to affective commitment for (a) non-profit and (b) private ownership types, relative to (c) public ownership. Performance appraisal is found to have no significant relationship with affective commitment for public ( $\beta=-0.01$; ns) or non-profit ( $\beta=-0.21$; ns) ownership types, but for private ownership performance appraisal $(\beta=0.28 ; p \leq 0.1)$ does hold a significant positive direct effect, providing support for hypothesis 2(b) only.

Hypothesis 3 expected that PRP is positively related to affective commitment for (a) nonprofit and (b) private ownership types, but (c) negatively related to affective commitment for public ownership. PRP has no significant relationship with affective commitment for public $(\beta=$ -0.04 ; ns), non-profit ( $\beta=0.04$; ns) or private ( $\beta=-0.17$; ns) ownership types, so taken collectively hypothesis 3 is not supported.

\section{...Insert Table 2 About Here...}

\section{Outcomes}

Hypothesis 4 proposed that affective commitment is positively related to business performance for (a) non-profit and (b) private ownership types, but (c) negatively related for public ownership. Affective commitment has a significant positive direct effect on business performance for public ownership only ( $\beta=0.19 ; p \leq 0.05$ ), with non-profit ( $\beta=-0.07$; ns) and private ( $\beta=-0.12$; ns) ownership types reporting a nonsignificant relationship. Thus, refuting hypothesis $4(\mathrm{c})$ and providing no support for 4(a) or 4(b).

Hypothesis 5 posited that affective commitment is positively related to customer performance for (a) public, (b) non-profit, and (c) private ownership types. Affective commitment has a significant positive relationship with customer performance for public ( $\beta=$ 0.23; $p \leq 0.01$ ) ownership, but no significant relationship is fond for non-profit ( $\beta=0.07$; ns) or private ( $\beta=0.19$; $n s$ ) ownership types, supporting hypothesis 5(a) only. 
Hypothesis 6 expected affective commitment to be positively related to social performance for (a) public and (b) non-profit ownership types, but (c) negatively related for private ownership. The findings suggest that no ownership type realizes social performance advantages from their affective commitment (Public: $\beta=-0.09$; ns / Non-profit: $\beta=-0.18$; ns / Private: $\beta=0.35 ; n s$ ), providing no support for hypothesis 6 .

\section{...Insert Table 3 About Here...}

\section{Additional analysis}

With regard to training and performance appraisal, although differences between mean values for the three different ownership types are identified, no significant differences are found. However, in interpreting the mean values it is evident that training of employees in public ownership is lower when compared against non-profit and private ownership types. The same is found for performance appraisal. When PRP is considered, there is significant variation in the mean values presented between ownership types. Public ownership utilizes this tool much less than their private and non-profit counterparts. In addition, public ownership is found to have significantly lower affective commitment relative to external ownership types.

\section{...Insert Table 4 About Here...}

\section{Discussion and implications}

This study sought to examine whether ownership type influences the antecedents and outcomes of affective commitment. While the antecedent effects are largely consistent, with training observed to be a core driver of affective commitment and PRP deemed ineffective, the performance outcomes of affective commitment vary significantly between ownership types (see Figure 2). We observe further significant differences in the levels of PRP and affective commitment between types; uncovering further insights at the disaggregated level.

\section{...Insert Figure 2 About Here...}

Studies of affective commitment typically assume that its antecedents and performance legacies will not differ considerably within the public sector. This has resulted in the examination of public service organizations as a homogenous set. There certainly appears convergence in the positive effect of training across the different ownership types, as expected (though we caution against generalizing this to non-profits due to the non-significant regression model). This highlights the value employees attach to perceived organizational support in the public sector more generally (Kooij et al. 2010) and the positive crowding-in effect of intrinsic performance management tools. In contrast, extrinsic performance management tools appear to have a largely non-significant effect on affective commitment; though for private ownership performance appraisal is a tool to generate increased affective commitment. Non-significant effects of PRP are reported for all ownership types, and this refutes the proposition that commitment among external ownership types would respond more positively to this extrinsic performance management tool than public ownership. Based on the 'antecedent' findings, then, intrinsic performance management reinforces employee interest in or enjoyment of their work, 
generating commitment for public and private ownership types. In contrast, despite extrinsic performance management tools experiencing resurgence in popularity (Bellé 2015), the crowding-out effect of appraisal (in most cases) and PRP (in all cases) appears to work against the generation of commitment across ownership types.

Based on the 'outcome' findings for external ownership types, affective commitment does not play a role in realizing service performance improvements. This suggests that the relationship between commitment and performance is more complex than anticipated in these external ownership contexts, which supports the findings of Carlos Pinho et al. (2014). On the other hand, public ownership does experience positive performance effects. To our surprise, affective commitment has a significant positive relationship with business performance under public ownership and this is augmented by a customer performance legacy, which was anticipated. The outcome findings, thus, challenge the general consensus in the public management literature that affective commitment is always positive for performance (e.g. Kim 2005; Mostafa et al. 2015), and highlights the dangers of assuming a general theory of affective commitment (as explained in detail by O’Toole and Meier 2015). Affective commitment, then, appears central to performance for public ownership, consistent with Lyons et al.'s (2006) contention that the intrinsic and altruistic values of public servants drive public service performance. However, we extend this evidence base further as our findings only hold for public ownership (we discount a positive effect for external ownership types) and includes measured business performance and valued customer performance outcomes (rather than just a distal organizational outcome). Thus, adopting a service-lens approach, for public ownership committed employees become more effective facilitators of service interactions and this carries multiple performance benefits. This is not the case for external ownership types.

Nevertheless, the additional analysis confirms that external ownership types are more likely to display affective commitment relative to public ownership, consistent with the crosssector findings of Goulet and Frank (2002), Boyne (2002), and Lyons et al. (2006). This may be a consequence of training being adopted less by public ownership, in turn reducing its positive antecedent effect when deployed alongside extrinsic performance management tools. As Jacobsen and Andersen (2014, 1012) note, 'motivation crowding theory argues that incentives and commands have not only positive price/disciplining effects, but also a motivation crowding effect aimed at intrinsic motivation'. In other words, the presence of performance appraisal and PRP might be serving to crowd-out the intrinsically incentivizing role of training, i.e. extrinsic rewards crowd-out and undermine intrinsic reward and, thus, commitment (Frey and Jegen 2001). To explain the presence of this crowding-out effect for public ownership, three conditions are assumed: (1) intrinsic motivation was present before crowding-out occurred, (2) employees perceive performance appraisal and PRP as controlling mechanisms for desired ends, and (3) the price effect (i.e. motivation induced by extrinsic rewards such as money) does not compensate for the decline in intrinsic motivation (Frey, Homberg and Osterloh 2013). To counter these conditions and ensure a positive crowding effect, public ownership should invest in training and reduce resource investment in extrinsic performance management tools for higher affective 
commitment. Doing so will support sustainability in the service offering, as suggested by the SERVICE framework (Osborne et al. 2015), through the generation of business and customer performance. While external ownership types should not expect business, customer, and social performance gains from commitment that is not to say that commitment in itself is not desirable.

\section{Limitations and future research}

The study has a number of limitations, which are now considered. First, data is drawn from a cross-sectional research design so we are not able to track the relationship between performance management tools and affective commitment, or affective commitment and performance, over time. Second, data is reported by a single-informant and we are, therefore, unable to consider the role of affective commitment across organizational levels. Third, focusing on a single service setting allowed for contextual variation to be examined. However, this limits the generalizability of our findings to other public service settings where different ownership types do not coexist. Finally, secondary data on social performance was not available for the whole sample, resulting in lower sample sizes across the three ownership types on this specific dimension. Nevertheless, we were conscious not to unintentionally fall foul of data dredging and hypothesizing after results are known, where only the statistically significant results would be presented (Starbuck 2016). Thus, despite the lack of correlation between this outcome and other study variables, we felt that its inclusion was essential.

Approaches to public sector reform have applied, often too uncritically, lessons derived from the private sector without sufficient adaptation to the needs of the public sector (Radnor and Walley 2008). The use of extrinsic performance management tools is a case in point. This has led to a view of public services guided by production rather than service logics (Radnor and Osborne 2013). Recent attempts to readdress this balance toward value creation include an adaptation of Moore’s strategic triangle (Bryson, Sancino, Benington, and Sørensen 2017), the SERVICE framework (Osborne et al. 2015), and service-profit chain (Kamakura, Mittal, De Rosa, and Mazzon 2002). Yet, public management is context specific and the peculiarities of 'setting' should not be overlooked. Therefore, we support the call for future research to establish if different expectations, goals, and pressures can be reconciled between ownership types within the service network for public value creation (Hodgkinson, Hannibal, Keating, Chester Buxton, and Bateman 2017). A qualitative investigation would be appropriate here to shift the public management narrative on ownership away from emotion, opinion, assumption, and normative bias (Anderson and Taggart 2016) toward service values and public value creation.

\section{Conclusion}

Though NPM is, in part, built on the model of the 'self-interested homo economicus' (Frey et al. 2013), extrinsic performance management tools are observed to be mostly inappropriate for building affective commitment (cf. Miao et al. 2013). In contrast, training as an intrinsic performance management tool is pivotal to generating affective commitment across public and private ownership types. It is the performance legacies of affective commitment, however, where 
ownership type has the greatest impact. Affective commitment triggers business performance and customer performance returns for public ownership. In contrast, whether employees of external ownership types display affective commitment or not, performance outcomes are not directly affected. Clearly other attitudes and/or behaviors are at play here and this points to greater complexity in the commitment-performance relationship in these ownership settings (Carlos Pinho et al. 2014).

Rather than drawing broad inferences on the antecedents and outcomes of affective commitment, the peculiarities of service settings must not be overlooked as different significant relationships are likely present, as reported here. Performance management tools, then, cannot and should not simply be 'plugged and played' from one context to another; nor should affective commitment be assumed to drive positive service outcomes across the public sector.

\section{Acknowledgements}

We thank the three anonymous reviewers for their constructive comments and support.

\section{References}

Alonso, J. M., R. Andrews, and I. R. Hodgkinson. 2016. "Institutional, Ideological and Political Influences on Local Government Contracting: Evidence from England.” Public Administration 94 (1): 244-262.

Andersen, L. B., A. Boesen, and L.H. Pedersen. 2016. "Performance in Public Organizations: Clarifying the Conceptual Space.” Public Administration Review 76 (6): 852-862.

Andrews, R., G. A. Boyne, and R. M. Walker. 2011. "Dimensions of Publicness and Organizational Performance: A Review of the Evidence.” Journal of Public Administration Research and Theory 21 (3): 301-319.

Andersen, L. B. and M. Jakobsen. 2011. "Does Ownership Matter for the Provision of Professionalized Services? Hip Operations at Publicly and Privately Owned Clinics in Denmark.” Public Administration 89 (3): 956-974.

Anderson, D. M. and G. Taggart. 2016. “Organizations, Policies, and the Roots of Public Value Failure: The Case of For-Profit Higher Education.” Public Administration Review 76 (5): 779-789.

Audit Commission. 2006. Public Sports and Recreation Services: Making Them Fit for the Future. Audit Commission for Local Authorities and the National Health Service in England.

Bartlett, K. R. 2001. “The Relationship between Training and Organizational Commitment: A Study in the Health Care Field.” Human Resource Development Quarterly, 12 (4): 335-352.

Becker, T. E., R. S. Billings, D. M. Eveleth, and N. L. Gilbert. 1996. "Foci and Bases of Employee Commitment: Implications for Job Performance.” The Academy of Management Journal 39 (2): 464-482.

Bellé, N. 2015. "Performance-Related Pay and the Crowding Out of Motivation in the Public Sector: A Randomized Field Experiment.” Public Administration Review 75 (2): 230-241.

Bennett, J., E. Iossa, and G. Legrenzi. 2003. "The Role of Commercial Non-profit Organizations in the Provision of Public Services.” Oxford Review of Economic Policy 19 (2): 335-347.

Boyne, G. A. 2002. "Public and Private Management: What's the Difference?” Journal of Management Studies 39 (1): 97-122. 
Boyne, G. A. 2003. "Sources of Public Service Improvement: A Critical Review and Research Agenda.” Journal of Public Administration Research and Theory 13 (3): 367-394.

Brown, M., D. Hyatt, and J. Benson. 2010. “Consequences of the Performance Appraisal Experience.” Personnel Review 39 (3): 375-396.

Bryson, J., A. Sancino, J. Benington, and E. Sørensen. 2017. "Towards a Multi-Actor Theory of Public Value Co-Creation.” Public Management Review 19 (5): 640-654.

Bullock, J. B., J. M. Stritch, and H. G. Rainey. 2015. "International Comparison of Public and Private Employees’ Work Motives, Attitudes, and Perceived Rewards.” Public Administration Review 75 (3): 479-489.

Butterfield, R., C. Edwards, and J. Woodall. 2004. "The New Public Management and the UK Police Service: The role of the Police Sergeant in the Implementation of Performance Management.” Public Management Review 6 (3): 395-415.

Campbell, J. W., H. Lee, and T. Im. 2016. “At the Expense of Others: Altruistic Helping Behaviour, Performance Management and Transformational Leadership”. Public Management Review 18 (6): 795-818.

Carlos Pinho, J., A. P. Rodrigues, and S. Dibb. 2014. “The Role of Corporate Culture, Market Orientation and Organisational Commitment in Organisational Performance: The Case of Non-Profit Organisations.” Journal of Management Development 33 (4): 374-398.

Castaing, S. 2006. "The effects of psychological contract fulfilment and public service motivation on organizational commitment in the French civil service.” Public Policy and Administration 21 (1): 84-98.

Christensen, R. K., S. W. Whiting, T. Im, E. Rho, J. M. Stritch, and J. Park. 2013. "Public Service Motivation, Task, and Non-Task Behavior: A Performance Appraisal Experiment with Korean MPA and MBA Students.” International Public Management Journal 16 (1): 28-52.

Deckop, J. R., R. Mangel, and C. C. Cirka. 1999. “Getting More than You Pay For: Organizational Citizenship Behaviour and Pay-For-Performance Plans.” The Academy of Management Journal 42 (4): 420-428.

Delaney, J. T., and M. A. Huselid. 1996. "The Impact of HR Management Practices on Perceptions of Organizational Performance.” The Academy of Management Journal 39 (4): 949-969.

Entwistle, T., and S. Martin. 2005. "From Competition to Collaboration in Public Service Delivery: A New Agenda for Research.” Public Administration 83 (1): 233-242.

Frey, B. S., F. Homberg and M. Osterloh. 2013. "Organizational Control Systems and Pay-ForPerformance in the Public Service.” Organization Studies 34 (7): 949-972.

Frey, B. S. and R. Jegen. 2001. “Motivation Crowding Theory.” Journal of Economic Surveys 15 (5): 589-611.

Gould-Williams, J. 2004. “The Effects of 'High Commitment' HRM Practices On Employee Attitudes: The Views of Public Sector Workers.” Public Administration 82 (1): 63-81.

Giauque, D., S. Anderfuhren-Biget, and F. Varone. 2013. "HRM Practices, Intrinsic Motivators, and Organizational Performance in the Public Sector.” Public Personnel Management 42 (2): 123-150.

Heinrich, C. J. and G. Marschke. 2010. "Incentives and their dynamics in public sector performance management systems.” Journal of Policy Analysis and Management 29 (1): 183-208.

Hansen, J. R., and E. Ferlie. 2016. “Applying Strategic Management Theories in Public Sector Organizations: Developing a Typology.” Public Management Review 18 (1): 1-19. 
Hansen, J. R., and A. M. Kjeldsen. 2017. "Comparing Affective Commitment in the Public and Private Sectors: A Comprehensive Test of Multiple Mediation Effects.” International Public Management Journal (in press). Doi: 10.1080/10967494.2016.1276033.

Hodgkinson, I.R., C. Hannibal, B.W. Keating, R. Chester Buxton, and N. Bateman. 2017. "Toward a Public Service Management: Past, Present, and Future Directions.” Journal of Service Management 28 (5): 998-1023.

Hodgkinson, I. R., and P. Hughes. 2014. "Strategy Content and Public Service Provider Performance in the UK: An Alternative Approach.” Public Administration 92 (3): 707-726.

Jacobsen, C. B., and L. B. Andersen. 2014. "Performance Management in the Public Sector: Does It Decrease or Increase Innovation and Performance?” International Journal of Public Administration 37 (14): 1011-1023.

Jacobsen, C. B., J. Hvitved, and L. B. Andersen. 2014. "Command and Motivation: How the Perception of External Interventions Relates to Intrinsic Motivation and Public Service Motivation.” Public Administration 92 (4): 790-806.

Kamakura, W. A., V. Mittal, F. De Rosa, and J. A. Mazzon. 2002. “Assessing the Service-Profit Chain.” Marketing Science 21 (3): 294-317.

Kim, S. 2005. "Individual-Level Factors and Organizational Performance in Government Organizations.” Journal of Public Administration Research and Theory 15 (2): 245-261.

Kooij, D. T., P. G. Jansen, J. S. Dikkers, and A. H. De Lange. 2010. “The Influence of Age on the Associations between HR Practices and Both Affective Commitment and Job Satisfaction: A Meta-Analysis.” Journal of Organizational Behavior 31 (8): 1111-1136.

Kroll, A., and D. P. Moynihan. 2015. "Does Training Matter? Evidence from Performance Management Reforms.” Public Administration Review 75 (3): 411-420.

Lyons, S. T., L.E. Duxbury, and C.A. Higgins. 2006. “A Comparison of the Values and Commitment of Private Sector, Public Sector, and Parapublic Sector Employees.” Public Administration Review 66 (4): 605-618.

Markovits, Y., A. J. Davis, D. Fay, and R. van Dick. 2010. "The Link between Job Satisfaction and Organizational Commitment: Differences Between Public and Private Sector Employees.” International Public Management Journal 13 (2): 177-196.

Martin, S., and J. Hartley. (2000). "Best Value for All? An Empirical Analysis of Local Government's Capacity to Implement Best Value Principles.” Public Management Review 2 (1): 43-56.

Meyer, J.P., D.J. Stanley, L. Herscovitch, and L. Topolnytsky. 2002. “Affective, Continuance, And Normative Commitment to the Organization: A Meta-Analysis of Antecedents, Correlates, and Consequences.” Journal of Vocational Behavior 61 (1): 20-52.

Miao, Q., A. Newman, Y. Sun, and L. Xu. 2013. "What Factors Influence the Organizational Commitment of Public Sector Employees in China? The Role of Extrinsic, Intrinsic and Social Rewards.” The International Journal of Human Resource Management 24 (17): 3262-3280.

Mostafa, A. M. S., J. S. Gould-Williams, and P. Bottomley. 2015. "High-Performance HR Practices and Employee Outcomes: The Mediating Role of Public Service Motivation.” Public Administration Review 75 (5): 747-757.

Moynihan, D. P. and S.K. Pandey. 2007. "Finding Workable Levers over Work Motivation: Comparing Job Satisfaction, Job Involvement, and Organizational Commitment.” Administration \& Society 39 (7): 803-832. 
Osborne, S. P., Z. Radnor, T. Kinder, and I. Vidal. 2015. “The SERVICE Framework: A Public-ServiceDominant Approach to Sustainable Public Services.” British Journal of Management 26 (3): 424438.

O’Toole, L. J., and K. J. Meier. 2015. "Public Management, Context, and Performance: In Quest of a More General Theory.” Journal of Public Administration Research and Theory 25 (1): 237-256

Park, S. M. and H. G. Rainey. 2007. "Antecedents, Mediators, and Consequences of Affective, Normative, and Continuance Commitment: Empirical Tests of Commitment Effects in Federal Agencies.” Review of Public Personnel Administration 27 (3): 197-226.

Perry, J. L., T. A. Engbers, and S. Y. Jun. 2009. "Back to the Future? Performance-Related Pay, Empirical Research, and the Perils of Persistence.” Public Administration Review 69 (1): 39-51.

Poister, T. H. 2010. "The Future of Strategic Planning in the Public Sector: Linking Strategic Management and Performance.” Public Administration Review 70 (SI): S246-S254.

Radnor, Z., and S. P. Osborne. 2013. “Lean: A Failed Theory for Public Services?” Public Management Review 15 (2): 265-287.

Radnor, Z., and P. Walley. 2008. "Learning to Walk Before we try to run: Adapting Lean for the Public Sector.” Public Money and Management 28 (1): 13-20.

Reid, M., and H. Barrington. 1994. Training Interventions: Managing Employee Development. Institute of Personnel Development: London.

Snell, S. A., and J. W. Dean. 1992. “Integrated Manufacturing and HR Management: A Human Capital Perspective.” The Academy of Management Journal 35 (3): 467-504.

Spector, P. E., and M. T. Brannick. 1995. “The Nature and Effects of Method Variance in Organizational Research”, in C.L. Cooper and I.T. Robertson (Eds), International Review of Industrial and Organizational Psychology 10. Chichester: Wiley: 249-274.

Starbuck, W. H. 2016. "60th Anniversary Essay: How Journals Could Improve Research Practices in Social Science.” Administrative Science Quarterly 61 (2): 165-183.

Stazyk, E. C., S. K. Pandey, and B. E. Wright. 2011. "Understanding Affective Organizational Commitment: The Importance of Institutional Context.” The American Review of Public Administration 41 (6): 603-624.

Su, S., K. Baird, and B. Blair. 2013. "Employee Organizational Commitment in the Australian Public Sector.” The International Journal of Human Resource Management 24 (2): 243-264.

Vyas, L., C. S. Jung, and A. Shafiqul Huque. 2013. "Challenges for Public Service Capacity and the Role of Public Employee Training as a Moderator in India.” Public Management Review 15 (8): 11161136.

Weibel, A., K. Rost, and M. Osterloh. 2009. "Pay for Performance in the Public Sector-Benefits and (Hidden) Costs.” Journal of Public Administration Research and Theory 20 (2): 387-412.

Whitener, E. M. 2001. “Do ‘High Commitment’ Human Resource Practices Affect Employee Commitment? A Cross-Level Analysis Using Hierarchical Linear Modelling.” Journal of Management 27 (5): 515-535.

Williams, H. M., J. Rayner, and C. W. Allinson. 2012. "New Public Management and Organisational Commitment in the Public Sector: Testing a Mediation Model.” International Journal of HR Management 23 (13): 2615-2629. 
Figure 1. Affective commitment antecedents (model 1) and outcomes (model 2)

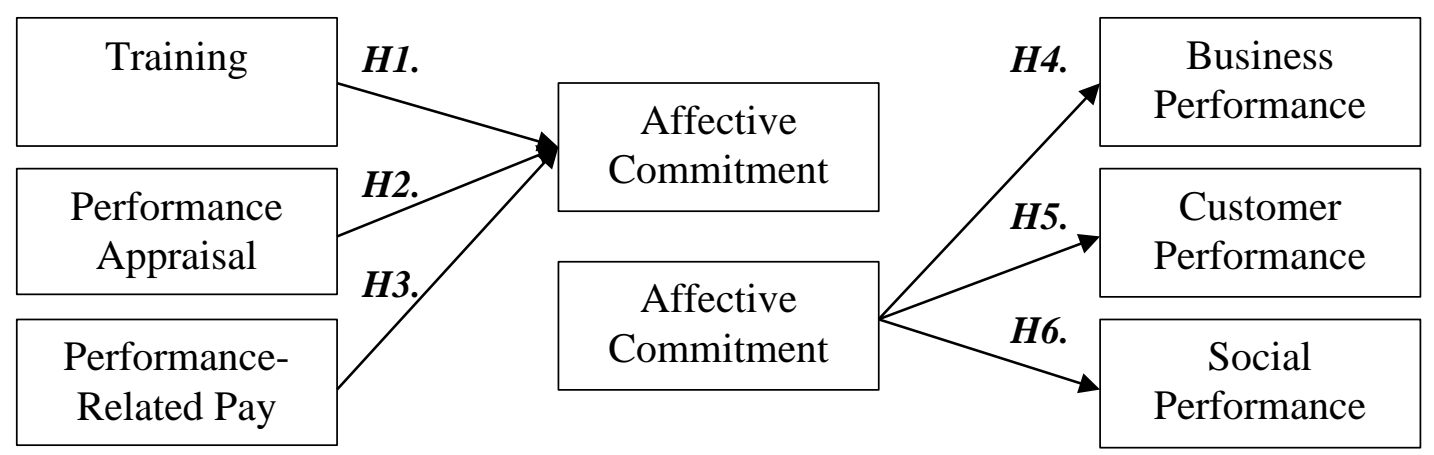

Figure 2. Significant findings: antecedents (model 1) and outcomes (model 2)

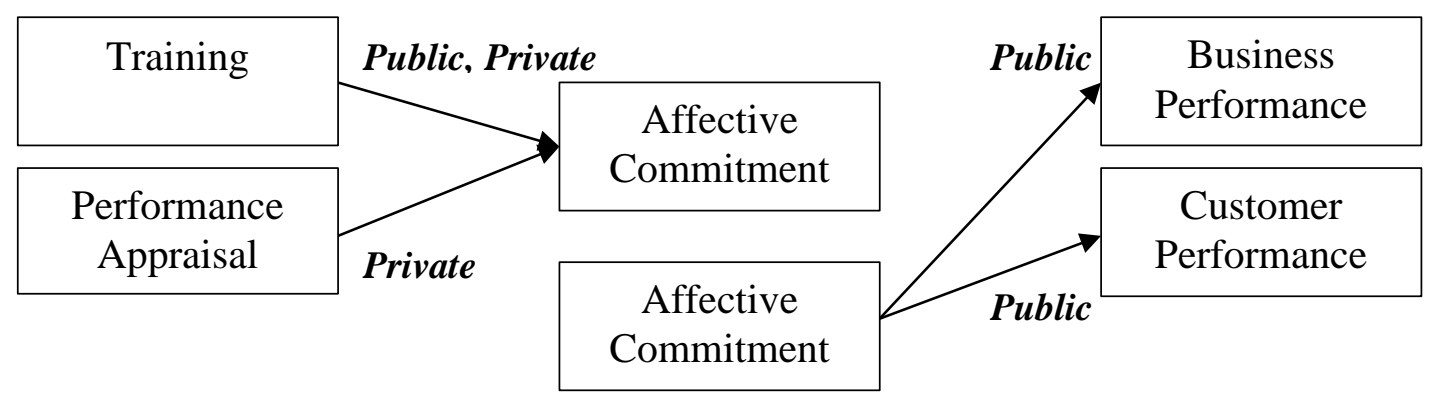


Table 1. Correlation results

\begin{tabular}{|c|c|c|c|c|c|c|c|c|}
\hline & & $\mathrm{X} 1$ & $\mathrm{X} 2$ & X3 & $\mathrm{X} 4$ & $\mathrm{X} 5$ & $\mathrm{X6}$ & $\mathrm{X7}$ \\
\hline $\mathrm{X} 1$ & Training & .78 & & & & & & \\
\hline \multirow[t]{2}{*}{$\mathrm{X} 2$} & Performance & & & & & & & \\
\hline & Appraisal & $.50 * *$ & .75 & & & & & \\
\hline X3 & $\begin{array}{l}\text { Performance- } \\
\text { related Pay }\end{array}$ & $.19 * *$ & .10 & .92 & & & & \\
\hline \multirow[t]{2}{*}{$\mathrm{X} 4$} & Affective & & & & & & & \\
\hline & Commitment & $.27 * *$ & $.16^{* *}$ & .07 & .67 & & & \\
\hline \multirow[t]{2}{*}{ X5 } & Business & & & & & & & \\
\hline & Performance & $.36^{* *}$ & $.23 * *$ & $.21^{* *}$ & $.23 * *$ & .73 & & \\
\hline \multirow[t]{2}{*}{ X6 } & Customer & & & & & & & \\
\hline & Performance & $.48^{* *}$ & $.37 * *$ & .11 & $.21^{* *}$ & $.55^{* *}$ & .74 & \\
\hline X7 & Social Performance & .19 & .16 & .18 & .19 & $-.41 * *$ & .17 & $n / a$ \\
\hline \multicolumn{2}{|c|}{ Mean } & 5.37 & 4.48 & 3.00 & 5.50 & 4.69 & 5.32 & 1.80 \\
\hline \multicolumn{2}{|c|}{ Max. } & 7.00 & 7.00 & 7.00 & 7.00 & 7.00 & 7.00 & 9.30 \\
\hline \multicolumn{2}{|c|}{ Min. } & 1.00 & 1.00 & 1.00 & 1.00 & 1.50 & 1.50 & .09 \\
\hline \multicolumn{2}{|c|}{ Standard Deviation } & 1.26 & 1.28 & 2.04 & 1.28 & 1.05 & .93 & 1.77 \\
\hline
\end{tabular}


Table 2. Regression results: Antecedents

\begin{tabular}{|c|c|c|c|c|c|}
\hline $\begin{array}{l}\text { Ownership } \\
\text { type }\end{array}$ & Independent Variable & & Dependent Variable & $\begin{array}{c}\text { Standardized } \\
\text { Coefficients }\end{array}$ & $t$-value \\
\hline \multirow[t]{3}{*}{ Public } & Training & $\rightarrow$ & Affective Commitment & .26 & $2.81^{*}$ \\
\hline & Performance Appraisal & $\rightarrow$ & Affective Commitment & -.01 & -.11 \\
\hline & Performance-related Pay & $\rightarrow$ & Affective Commitment & -.04 & -.44 \\
\hline \multirow{2}{*}{ Controls } & Pay \& Play & & & .09 & .96 \\
\hline & Membership & & & .04 & .39 \\
\hline \multicolumn{6}{|c|}{ Model Statistics } \\
\hline$R^{2}$ & & .08 & F-Value & & $2.58^{*}$ \\
\hline \multirow[t]{3}{*}{ Non-profit } & Training & $\rightarrow$ & Affective Commitment & .27 & $1.89^{\dagger}$ \\
\hline & Performance Appraisal & $\rightarrow$ & Affective Commitment & -.21 & -1.44 \\
\hline & Performance-related Pay & $\rightarrow$ & Affective Commitment & .04 & .33 \\
\hline \multirow{2}{*}{ Controls } & Pay \& Play & & & .11 & .81 \\
\hline & Membership & & & .01 & .08 \\
\hline \multicolumn{6}{|c|}{ Model Statistics } \\
\hline$R^{2}$ & & .07 & F-Value & & .89 \\
\hline \multirow[t]{3}{*}{ Private } & Training & $\rightarrow$ & Affective Commitment & .30 & $1.76^{\dagger}$ \\
\hline & Performance Appraisal & $\rightarrow$ & Affective Commitment & .28 & $1.64^{\dagger}$ \\
\hline & Performance-related Pay & $\rightarrow$ & Affective Commitment & -.17 & -1.26 \\
\hline \multirow{2}{*}{ Controls } & Pay \& Play & & & -.17 & -.89 \\
\hline & Membership & & & .18 & .99 \\
\hline \multicolumn{5}{|c|}{ Model Statistics } & $3.61 * *$ \\
\hline
\end{tabular}

Notes: ${ }^{* *} p \leq 0.01,{ }^{*} p \leq 0.05 ;{ }^{\dagger} p \leq 0.1$. 
Table 3. Regression results: Outcomes

\begin{tabular}{|c|c|c|c|c|c|}
\hline $\begin{array}{l}\text { Ownership } \\
\text { type }\end{array}$ & Independent Variable & & Dependent Variable & $\begin{array}{c}\text { Standardized } \\
\text { Coefficients }\end{array}$ & $t$-value \\
\hline Public & Affective Commitment & $\rightarrow$ & Customer Performance & .23 & $2.79^{* *}$ \\
\hline \multirow[t]{2}{*}{ Controls } & Pay \& Play & & & .13 & 1.35 \\
\hline & Membership & & & -.02 & -.22 \\
\hline \multicolumn{6}{|c|}{ Model Statistics } \\
\hline \multirow[t]{2}{*}{$R^{2}$} & & .07 & F-Value & & $3.82 * *$ \\
\hline & Affective Commitment & $\rightarrow$ & Business Performance & .19 & $2.34^{*}$ \\
\hline Controls & $\begin{array}{l}\text { Pay \& Play } \\
\text { Membership }\end{array}$ & & & $\begin{array}{r}.30 \\
-.02\end{array}$ & $\begin{array}{l}3.16^{* *} \\
-.21\end{array}$ \\
\hline \multicolumn{6}{|c|}{ Model Statistics } \\
\hline \multirow[t]{2}{*}{$R^{2}$} & & .14 & F-Value & & $7.28 * *$ \\
\hline & Affective Commitment & $\rightarrow$ & Social Performance & .09 & .45 \\
\hline \multirow{2}{*}{ Controls } & Pay \& Play & & & -.60 & $-2.71^{*}$ \\
\hline & Membership & & & .25 & 1.15 \\
\hline \multicolumn{6}{|c|}{ Model Statistics } \\
\hline \multicolumn{2}{|c|}{$R^{2}$} & .34 & F-Value & & $2.61^{\dagger}$ \\
\hline \multirow{2}{*}{$\begin{array}{l}\text { Non-profit } \\
\text { Controls }\end{array}$} & Affective Commitment & $\rightarrow$ & Customer Performance & .07 & .62 \\
\hline & $\begin{array}{l}\text { Pay \& Play } \\
\text { Membership }\end{array}$ & & & $\begin{array}{r}.20 \\
-.24\end{array}$ & $\begin{array}{c}1.45 \\
-1.76^{\dagger}\end{array}$ \\
\hline \multicolumn{6}{|c|}{ Model Statistics } \\
\hline \multirow[t]{2}{*}{$R^{2}$} & & .06 & F-Value & & 1.38 \\
\hline & Affective Commitment & $\rightarrow$ & Business Performance & .07 & .60 \\
\hline \multirow[t]{2}{*}{ Controls } & Pay \& Play & & & -.01 & -.05 \\
\hline & Membership & & & -.05 & -.34 \\
\hline \multicolumn{6}{|c|}{ Model Statistics } \\
\hline \multirow[t]{2}{*}{$R^{2}$} & & .01 & F-Value & & .18 \\
\hline & Affective Commitment & $\rightarrow$ & Social Performance & .18 & .64 \\
\hline \multirow[t]{2}{*}{ Controls } & Pay \& Play & & & .10 & .33 \\
\hline & Membership & & & .16 & .51 \\
\hline \multicolumn{5}{|c|}{ Model Statistics } & .43 \\
\hline \multirow{3}{*}{$\begin{array}{l}\text { Private } \\
\text { Controls }\end{array}$} & Affective Commitment & $\rightarrow$ & Customer Performance & .19 & 1.45 \\
\hline & Pay \& Play & & & -.40 & $-2.13^{*}$ \\
\hline & Membership & & & .28 & 1.43 \\
\hline \multicolumn{6}{|c|}{ Model Statistics } \\
\hline \multirow[t]{2}{*}{$R^{2}$} & & .13 & F-Value & & $2.45^{\dagger}$ \\
\hline & Affective Commitment & $\rightarrow$ & Business Performance & .12 & .92 \\
\hline \multirow{2}{*}{ Controls } & Pay \& Play & & & -.25 & -1.40 \\
\hline & Membership & & & .53 & $2.91 * *$ \\
\hline \multicolumn{6}{|c|}{ Model Statistics } \\
\hline \multirow[t]{2}{*}{$R^{2}$} & & .18 & F-Value & & $3.59 *$ \\
\hline & Affective Commitment & $\rightarrow$ & Social Performance & .35 & 1.59 \\
\hline \multirow[t]{2}{*}{ Controls } & Pay \& Play & & & .51 & $2.31 *$ \\
\hline & Membership & & & .04 & .16 \\
\hline Model Statisti & & & & & \\
\hline$R^{2}$ & & .40 & F-Value & & $2.85^{\dagger}$ \\
\hline
\end{tabular}

Notes: ${ }^{* *} p \leq 0.01,{ }^{*} p \leq 0.05 ;{ }^{\dagger} p \leq 0.1$. 
Table 4. Performance management and commitment between ownership types

\begin{tabular}{|c|c|c|c|c|c|}
\hline \multirow{2}{*}{$\begin{array}{l}\text { Performance } \\
\text { management / } \\
\text { Commitment }\end{array}$} & \multicolumn{3}{|c|}{ Ownership type (Means [SD]) } & \multirow[t]{2}{*}{$\overline{F-\text { ratio }}$} & \multirow[t]{2}{*}{ Scheffé Test $(p \leq .05)$} \\
\hline & Public & Non-profit & Private & & \\
\hline Training & $5.29(1.25)$ & $5.45(1.20)$ & 5.47 (1.39) & 8.44 & NSD \\
\hline $\begin{array}{l}\text { Performance } \\
\text { Appraisal }\end{array}$ & 4.37 (1.19) & 4.53 (1.39) & 4.72 (1.33) & 1.83 & NSD \\
\hline $\begin{array}{l}\text { Performance- } \\
\text { related Pay }\end{array}$ & 2.57 (1.99) & $3.40(2.07)$ & 3.72 (1.89) & $8.48^{* *}$ & $\begin{array}{l}\text { Public }<\text { Non-profit; } \\
\text { Public }<\text { Private }\end{array}$ \\
\hline $\begin{array}{l}\text { Affective } \\
\text { Commitment }\end{array}$ & $5.24(1.30)$ & $5.72(1.12)$ & 5.91 (1.27) & $7.23^{* *}$ & $\begin{array}{l}\text { Public }<\text { Non-profit; } \\
\text { Public }<\text { Private }\end{array}$ \\
\hline
\end{tabular}

